\title{
Triorganotin Isothiocyanates Affect Migration and Immune Check-point Receptors in Human Triple-negative Breast Carcinoma MDA-MB-231 Cells
}

\author{
LUBA HUNAKOVA ${ }^{1}$, EVA HORVATHOVA ${ }^{1}$, PAULINA GRONESOVA ${ }^{1}$, \\ PAVEL BOBAL ${ }^{2}$, JAN OTEVREL $^{2}$ and JULIUS BRTKO ${ }^{3}$ \\ ${ }^{I}$ Cancer Research Institute, Biomedical Research Center, University Science Park for Biomedicine, \\ Slovak Academy of Sciences, Bratislava, Slovak Republic; \\ ${ }^{2}$ Department of Chemical Drugs, Faculty of Pharmacy, \\ University of Veterinary and Pharmaceutical Sciences Brno, Brno, Czech Republic; \\ ${ }^{3}$ Institute of Experimental Endocrinology, Biomedical Research Center, \\ University Science Park for Biomedicine, Slovak Academy of Sciences, Bratislava, Slovak Republic
}

\begin{abstract}
Background/Aim: Triple-negative breast cancer (TNBC) constitutes $15-20 \%$ of all breast carcinomas, affecting younger women more often and has a worse prognosis than other types of breast cancer, due to the combination of more aggressive clinical behavior and lack of molecular targets for therapy. This study assessed the effects of non-genotoxic concentrations of tributyltin isothiocyanate (TBT-ITC) and triphenyltin isothiocyanate (TPT-ITC) on MDA-MB-231 cells. Materials and Methods: MTT assay, comet assay, kinetic imaging and flow cytometry were used for analysis of MDAMB-231 cells. Results: The results showed that $100 \mathrm{nM}$ concentration of TBT-ITC and TPT-ITC, that did not affect viability or DNA integrity, slowed-down migration by CD44 down-regulation. Moreover, both compounds demonstrated immunomodulatory properties, attenuating PD-L1 expression in MDA-MB-231 cells. Conclusion: TPT-ITC was more effective in down-regulating CD44 expression and reducing migration than TBT-ITC, while TBT-ITC was more potent in lowering PD-L1 expression in comparison with TPT-ITC.
\end{abstract}

Triple-negative breast cancer (TNBC) (estrogen-, progesteroneand HER2-receptor negative) harbors more aggressive clinical

Correspondence to: Luba Hunakova, Cancer Research Institute, Biomedical Research Center, University Science Park for Biomedicine, Slovak Academy of Sciences, Dubravska cesta 9, 845 05 Bratislava, Slovak Republic. Tel: +421 232295154, e-mail: exonhun@savba.sk

Key Words: Triorganotin isothiocyanate derivatives, nuclear retinoid $\mathrm{X}$ receptor, breast cancer, migration, immunomodulation, surface adhesive molecules, DNA damage. behavior than other types of breast cancer and still lacks targeted treatment options (1). Among them, there is hope that the emerging field of immunotherapy will bring progress. One interesting biomarker related to the immune/tumor interaction is programmed death-ligand 1 (PD-L1) (2).

Among a variety of organotin compounds, triorganotin derivatives have demonstrated marked cytotoxic properties against various tumor cell lines (3-5). They are expected to exert anti-cancer properties through different mechanisms at the molecular level $(6,7)$. Research on the biological properties of triorganotin compounds thus opens a new research subarea in experimental oncology $(4,8,9)$. They act as nuclear retinoid $\mathrm{X}$ receptor (RXR) agonists, due to their capacity to bind to the ligand-binding domain of RXR subtypes (10-12), and thus, may function as potent transcriptional activators $(4,10)$.

Various studies have demonstrated the anticancer effects of isothiocyanates (ITCs). Recent research has been focused on the possible therapeutic benefit of natural (13) or synthetic $(14,15)$ ITCs in cooperation with standard anticancer drugs. The anticancer efficacy of sulforaphane has been shown to be associated with the reversal of epithelial-mesenchymal transition, and with reduced production of pro-inflammatory cytokines and proangiogenic growth factors in MDA-MB-231 cells (16).

In our very recent study, we combined the anticancer/ genotoxic properties of two chemically different types of molecules, triorganotins and ITCs, into tributyltin isothiocyanate and triphenyltin isothiocyanate, and showed/compared their genotoxic effects in human breast carcinoma MCF 7 and MDA-MB-231 cells (17). Therefore, the aim of this study was to assess the biological effects of non-genotoxic concentrations of triorganotin isothiocyanates in the more aggressive, triple-negative MDA-MB-231 cells. 
Table I. DNA damage caused in human breast cancer MDA-MB-231 cells by the treatment with TBT-ITC and TPT-ITC expressed either as a mean percentage of tail DNA or as a percentage of StO-induced DNA migration.

\begin{tabular}{lcc}
\hline \multirow{2}{*}{ Samples } & \multicolumn{2}{c}{ Alkaline comet assay } \\
\cline { 2 - 3 } & $\begin{array}{c}\text { \% of mean } \\
\text { tail DNA }\end{array}$ & $\begin{array}{c}\text { \% of StO-induced } \\
\text { DNA migration }\end{array}$ \\
\hline Control & $6.39 \pm 3.23$ & $100.00 \pm 6.60$ \\
$300 \mu \mathrm{M} \mathrm{H} \mathrm{O}_{2}$ & $51.01 \pm 2.47^{\# \# \#}$ & \\
$20 \mu \mathrm{M} \mathrm{cisPt}$ & $3.00 \pm 0.74$ & $100.74 \pm 8.72$ \\
$100 \mathrm{nM} \mathrm{TBT}$ TITC & $4.71 \pm 1.52$ & $87.29 \pm 14.95$ \\
\hline
\end{tabular}

Data are shown as the means of three independent experiments \pm standard deviation (SD). Significant differences $\# \# \# p<0.001$ in comparison to control. $300 \mu \mathrm{M} \mathrm{H}_{2} \mathrm{O}_{2}$ and $20 \mu \mathrm{M}$ cisPt, positive controls for the respective assays.

\section{Materials and Methods}

Reagents. Tributyltin isothiocyanate (TBT-ITC) and triphenyltin isothiocyanate (TPT-ITC) were prepared by refluxing alcohol solutions of the respective tin chlorides with KSCN used in excess (1.5 equiv.), as previously described $(18,19)$. IR spectra were recorded on a SmartMIRacle ATR Zn/Se for Nicolet Impact 410 FTIR (Thermo Scientific, Langenselbold, Germany). NMR spectra were measured on a JEOL ECZR-400 MHz spectrometer (Jeol Ltd., Akishima, Tokyo, Japan). The purities of the prepared triorganotin compounds (tributyltin isothiocyanate and triphenyltin isothiocyanate) were better than $97 \%$, as determined by NMR (17).

Cells and treatment. The MDA-MB-231 human breast cancer cell line was routinely cultured in RPMI 1640 medium supplemented with $10 \%$ heat-inactivated FCS, $2 \mathrm{mM}$ L-glutamine, $100 \mu \mathrm{g} / \mathrm{ml}$ penicillin and $50 \mu \mathrm{g} / \mathrm{ml}$ streptomycin. Cells were plated at $3-6 \times 10^{4}$ cells $/ \mathrm{cm}^{2}$ density one day before treatment and exposed to $100 \mathrm{nM}$ concentration of TBT-ITC and TPT-ITC for the indicated time periods. Stock solutions of tested compounds were dissolved in ethanol and an equal volume of it (final concentration $<0.02 \%$ ) was added to the control cells.

Cytotoxicity test. The effect of tested compounds on survival of cells was determined by the MTT assay (20). Cells were seeded at $1-$ $2 \times 10^{3}$ cell density in 96-well culture plates. Each dose of tested compounds (added in the volume of $50 \mu \mathrm{l}$ ) was tested in triplicate or quadruplicate. After $48 \mathrm{~h}$, the cells were incubated with $50 \mu \mathrm{l}$ of 3-[4,5-dimethylthiazol-2-yl]-2,5-diphenyl tetrazolium bromide (MTT, $1 \mathrm{mg} / \mathrm{ml}$; Sigma-Aldrich Chemicals Co., Schnelldorf, Germany) and left in the dark at $37^{\circ} \mathrm{C}$ for an additional $4 \mathrm{~h}$. Thereafter, medium was removed, the formazan crystals were dissolved in $200 \mu \mathrm{l}$ of DMSO, and the absorbance was measured at 540 and $690 \mathrm{~nm}$ in an $\mathrm{xMark}^{\mathrm{TM}}$ Microplate Spectrophotometer (BioRad Laboratories, Inc., Vienna, Austria).

Alkaline single cell gel electrophoresis (alkaline comet assay). For the evaluation of DNA damage in MDA-MB-231 cells the alkaline
MDA-MB-231 MTT 48h

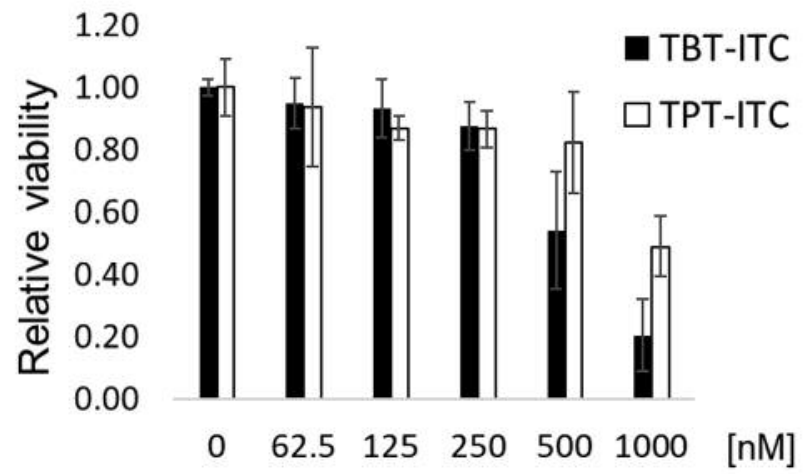

Figure 1. Cytotoxicity of triorganotin isothiocyanates (TBT-ITC and TPT-ITC) in MDA-MB-231cells. Relative viability was measured by the MTT test following treatment with various concentrations of triorganotin isothiocyanates for $48 \mathrm{~h}$.

comet assay described by Gabelova et al. (21) was precisely followed. The positive control in this conventional assay was treated with hydrogen peroxide ( $300 \mu \mathrm{M} \mathrm{H}_{2} \mathrm{O}_{2}$; Sigma-Aldrich Chemicals Co.) in PBS at $4^{\circ} \mathrm{C}$ for $5 \mathrm{~min}$ in a fridge. To verify that the compounds tested ( $24 \mathrm{~h}$ treatment) induce crosslinks, the cells were exposed to styrene oxide (StO; Sigma-Aldrich Chemicals Co.) before the lysis step according to Hunakova et al. (13). The positive control was treated for $24 \mathrm{~h}$ with crosslinking cisplatin $(20 \mu \mathrm{M}$ cisPt; Lachema, Czech Republic). At least one hundred of ethidium bromide (EtBr; Sigma-Aldrich Chemicals Co.)-stained nucleoids per three parallel slides per sample in one experiment were examined using a Carl Zeiss AxioImager.Z2 fluorescence microscope attached to a computerized image analysis Metafer 5 (MetaSystems GmbH, Germany). The mean percentage of DNA in the tail was used as a parameter for the measurement of DNA damage and for the presentation of the conventional comet assay data. Results from the detection of crosslinks are shown as percentages of StO-induced DNA migration calculated using the formula suggested by Hunakova et al. (13). The obtained results underwent analysis using the SPSS 23.0 software. The Shapiro-Wilk test was used to test the normality of data distribution. Differences between more than two groups were assessed by one-way analysis of variance (ANOVA) and by the Bonferroni or Tamhane's test for multiple comparisons. Non-normally distributed data were tested by Kruskal-Wallis $\mathrm{H}$ test and by multiple comparisons. Differences of $p<0.05$ were considered as significant.

Flow cytometry. Surface antigen expression was determined by multicolour flow cytometry using CANTO II, Becton Dickinson flow cytometer equipped with 3 lasers (violet $405 \mathrm{~nm}$, blue $488 \mathrm{~nm}$ and red $633 \mathrm{~nm}$ ). Cells were harvested by trypsinization, adjusted to $10^{6}$ cells $/ \mathrm{ml}$ and washed with PBS. Isotype-matched non-reactive monoclonal antibodies (eBioscience, San Diego, CA, USA), mouse monoclonal fluoro-isothiocyanate (FITC)-labeled anti-CD44v6 (BD Pharmingen, San Jose, CA, USA), phycoerythrin (PE)-labeled antiCD44 (Exbio, Prague, Czech Republic) or PE-labeled anti-PD-L1 (kindly provided by Jana Jakubikova, PhD, Cancer Research Institute, Biomedical Research Center, University Science Park for 


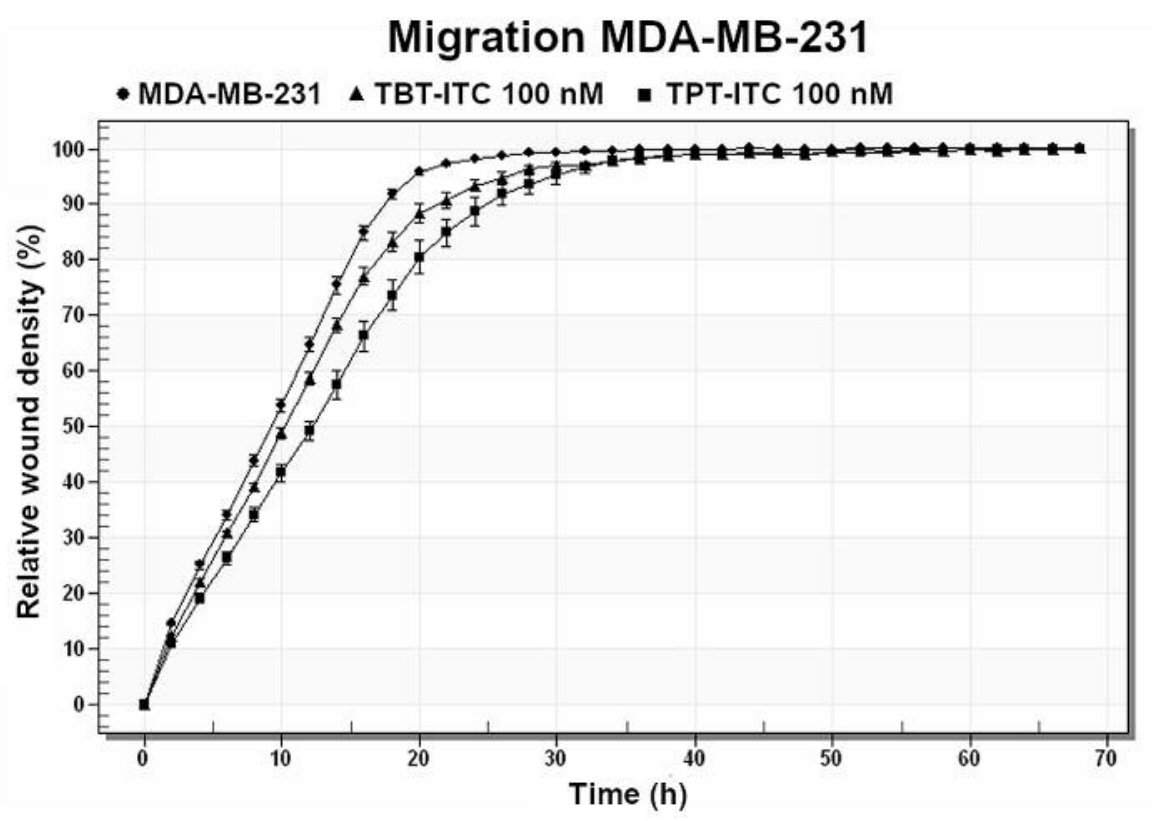

Figure 2. Migration assay. Relative wound closure was measured after creating the scratch wound by wound making tool in MDA-MB-231 cells treated with $100 \mathrm{nM}$ TBT-ITC, $100 \mathrm{nM}$ TPT-ITC, or culture medium (control). Images were taken every $2 \mathrm{~h}$ for the next $70 \mathrm{~h}$ using the IncuCyte ZOOM $^{T M}$ Kinetic Imaging System and evaluated by IncuCyte ZOOM ${ }^{T M} 2013$ A software.

Biomedicine, Slovak Academy of Sciences, Bratislava, Slovak Republic) were added to tube containing a $50 \mu \mathrm{l}$ aliquot of cells according to the instructions of the manufacturer. Cells were incubated at room temperature for 30 minutes. 4',6-diamidino-2phenylindole (DAPI; Sigma-Aldrich Chemicals Co.) fluorescence was used to exclude dead cells from the analysis. Data were exported and analyzed in FCS Express 4.0 (De Novo Software). Mean of fluorescence intensity of each positive parameter (CD44, CD44v6 and PD-L1) was acquired after exporting statistics in an individual projection. Only viable (DAPI negative) cells were analyzed by FCS Express 4.0 (De Novo Software).

Migration assay. Forty thousand MDA-MB-231 cells per well were plated in triplicates in ImageLock 96-well plates (Essen BioScience, Welwyn Garden City, UK) and let to adhere for $16 \mathrm{~h}$. Confluent monolayers were wounded with wound making tool (Essen BioScience), washed twice, and supplemented with $100 \mathrm{nM}$ TBTITC, $100 \mathrm{nM}$ TPT-ITC, or culture medium. Images were taken every $2 \mathrm{~h}$ for the next $70 \mathrm{~h}$ by the IncuCyte $\mathrm{ZOOM}^{\mathrm{TM}}$ Kinetic Imaging System and evaluated by IncuCyte ZOOM ${ }^{\mathrm{TM}}$ 2013A software (Essen BioScience) based on the relative wound density measurements.

\section{Results}

Based on the MTT analysis (Figure 1), $100 \mathrm{nM}$ concentration of the studied compounds were selected for in vitro experiments. At this concentration, viability of cells was over $93 \%$ for TBT-ITC and over $95 \%$ for TPT-ITC.

Conventional comet assay (determination of DNA breaks) and its slight modification used for the detection of crosslinks revealed the presence of neither of them (Table I) in the population of MDA-MB-231 cells after $24 \mathrm{~h}$ treatment with both ITC derivatives. These results indicated that $100 \mathrm{nM}$ of TBT-ITC or TPT-ITC have no genotoxic effects.

Under these conditions both tested compounds were able to slow-down the migration of highly invasive MDA-MB-231 cells (Figure 2) as shown by the migration assay using the IncuCyte ZOOM ${ }^{\mathrm{TM}}$ Kinetic Imaging System. Relative wound density, measured $22 \mathrm{~h}$ after creating the scratch wound, returned to $97 \%$ in control cells, and to $90 \%$ in TBT-ITCtreated $(100 \mathrm{nM})$ and $85 \%$ in TPT-ITC-treated $(100 \mathrm{nM})$ cells.

Flow cytometry revealed that the anti-migration effect of triorganotin isothiocyanates (TBT-ITC and TPT-ITC) was associated with down-regulation of CD44 cell surface antigen, but not of its CD44v6 variant (Figure 3), expression of which was only negligible in our setting. Similarly to migration reduction, TPT-ITC was more effective than TBT-ITC.

The immunomodulatory properties of the tested derivatives were demonstrated again by flow cytometry. Incubation of cells with $100 \mathrm{nM}$ concentration of both drugs for $24 \mathrm{~h}$ resulted in down-regulation of PD-L1 (Figure 4). Our results showed higher efficacy of TBT-ITC in comparison with TPT-ITC.

\section{Discussion}

Better understanding of mechanisms that guide tumor growth and invasion and quest for agents that could inhibit these 

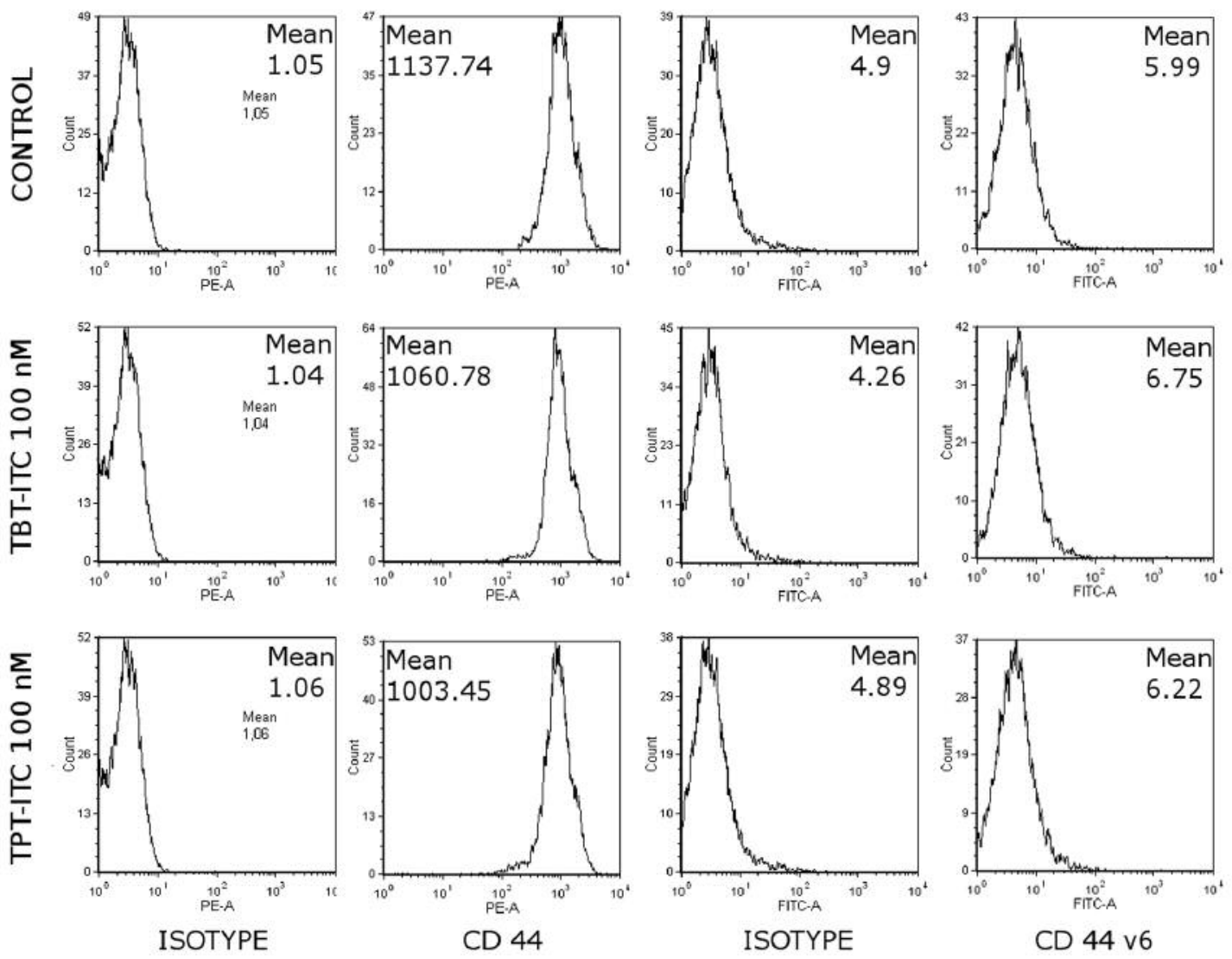

Figure 3. CD44 and CD44v6 staining, as determined by flow cytometry. Representative histograms (number of cells vs. fluorescence intensity) of CD44 (PE) and CD44v6 (FITC) expression, in MDA-MB-231 cells incubated with triorganotin isothiocyanates (TBT-ITC and TPT-ITC) for 24 h. Isotype-matched monoclonal antibodies were used as negative controls.

processes are important in combating dissemination of cancer. We explored the effects of non-toxic and non-DNAdamaging doses of triorganotin ITCs on various features of metastatic breast cancer MDA-MB-231 cells.

Recently, these compounds underwent investigation of their cytotoxic effects in both human estrogen receptor positive MCF 7 and triple-negative MDA-MB-231 breast carcinoma cells (17). We showed that the DNA damage induced by TBT-ITC and TPT-ITC was the main cause of their cytotoxicity in breast cells studied. Previously, we have studied selected Sn- and Ge-triorganometallic compounds and have reported different cytotoxic and migration modulatory effects on triple-negative breast cancer MDAMB-231 cells (7).

In this work, we demonstrated that triorganometallic isothiocyanates inhibited migration of these cells more effectively than Sn- and Ge-triorganometallic compounds. Comparing to tributyltin chloride (TBT-Cl) and triphenyltin chloride (TPT-Cl), their isothiocyanate derivatives sloweddown the migration of metastatic MDA-MB-231 cells differently; TBT-ITC was less effective and TPT-ITC was more effective than TBT-Cl and TPT-Cl, respectively (5).

Modulation of migration potential was found to be associated with CD44 (receptor for hyaluronic acid) downregulation. The CD44 glycoproteins play multifaceted roles in tumor progression and metastasis, being associated with stem-like breast cancer cells (22). Among the CD44 spliced variants, one of the v6 exon-containing isoforms confers metastatic potential to non-metastatic cells (23). Recently, it has been reported that the CD44v6 isoform had the highest expression levels in non-metastatic breast cancer cells (MCF 7 ) in comparison to metastatic breast cancer cells (MDAMB-231). Indeed, in our setting, we also found only negligible expression of CD44v6 isoform on the surface of MDA-MB-231 cells. However, we worked in normoxic conditions and the expression of CD44 and its variant isoforms (CD44v6, CD44v7/8) is known to be increased in triple-negative breast cancer cells under hypoxic conditions (22). Our data are in agreement with the finding of others who have also indicated that the expression of CD44 was 

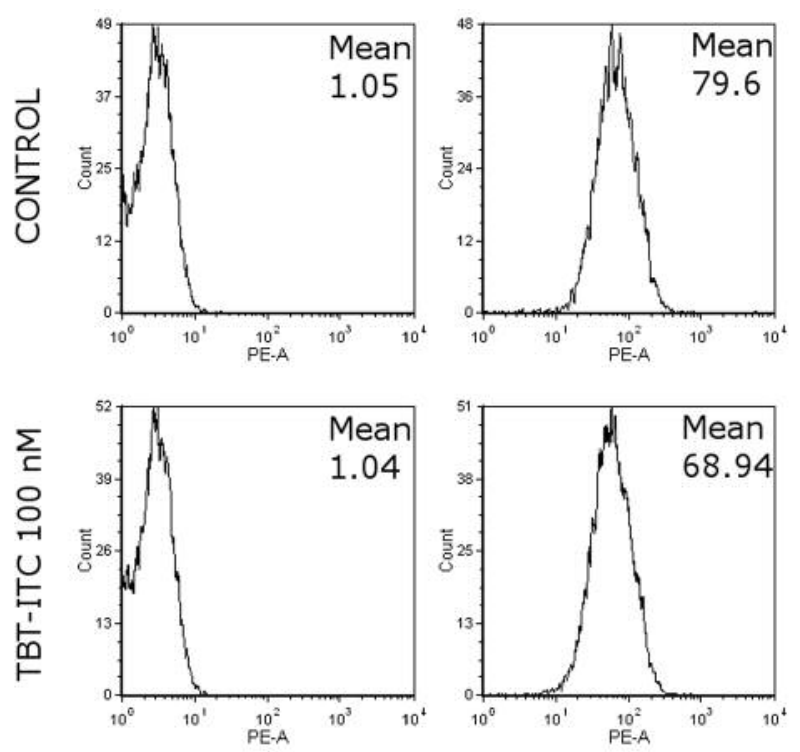

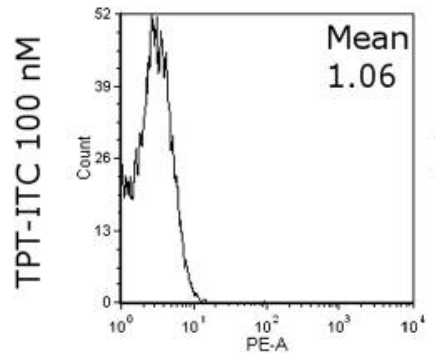

ISOTYPE

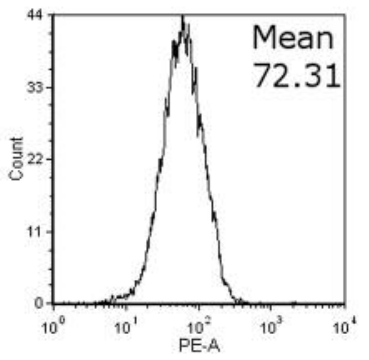

PDL-1
Figure 4. PD-L1 expression determined by flow cytometry. Representative histograms of $P D-L 1$ expression modulated by triorganotin isothiocyanates (TBT-ITC and TPT-ITC) after $24 \mathrm{~h}$ incubation of MDA-MB-231 cells.

involved in triple-negative breast cancer cells migration (24).

In the last part of our study, we addressed modulation of immune checkpoint proteins such as PD-L1. Recently, PDL1 expression was related to poor prognosis in patients with gastric cancer (25). Research in PD-L1 in TNBC has, so far, given diverse and sometimes contradictory results. Programmed death 1 receptor (PD-1) is expressed in activated T-lymphocytes, B-lymphocytes, mononuclear cells, NK cells and some DCs (26). When PD-1 binds to its ligand PD-L1, it serves to down-regulate T-cell activity. Herein, we reported down-regulation of PD-L1 molecule on the surface of MDA-MB-231 cells after the $24 \mathrm{~h}$ TBT-ITC and TPT-ITC treatment. In contrast to modulation of migration, TBT-ITC was more potent in down-regulating PD-L1 than TPT-ITC. This suggests that the tested compounds could prevent the undesirable PD-1/PD-L1 interaction which can suppress the anticancer tumor response. In a study including 35 triplenegative, non-basal-like tumors and 69 basal-like tumors, high expression of PD-L1 was found in $31 \%$ and $33 \%$, respectively (27). Mittendorf et al. (28) have found higher expression of PD-L1 in TNBC, than in other cancer types. However, the impact of high expression of PD-L1 on overall prognosis of breast cancer is still debated $(29,30)$. Preliminary results of ongoing clinical trials targeting the PD-1/PD-L1 pathway to treat TNBC patients have been promising $(31,32)$.

To summarize our present results, we demonstrated that TBT-ITC was more potent in down-regulating PD-L1, an immune regulatory molecule that suppress the anticancer tumor response, while TPT-ITC was more effective in downregulating $\mathrm{CD} 44$ expression and reducing migration compared to TBT-ITC. Interest in organotin (IV) novel compounds are undoubtedly increasing due to their possible medical uses and thorough investigation of both their genotoxic, as well as non-genotoxic anticancer actions is required.

\section{Conflicts of Interest}

None of the Authors have any conflict of interest to declare regarding this study.

\section{Authors' Contributions}

L.H., E.H., and P.G. conceived, designed and performed the experiments and analyzed the data; J.O. and P.B. synthesized TBTITC and TPT-ITC; J.B. drafted the paper and assisted with the final processing of the manuscript.

\section{Acknowledgements}

The Authors thank Bozena Smolkova, PhD. for her assistance with the statistics as well as Erika Durinikova, PhD. and Svetlana Miklikova, PhD. for their excellent help with the wound making tool. The authors appreciate the skillful assistance of Mrs. Margita Sulikova and Mrs. Anna Kovarikova. Supported by APVV-15-0372, VEGA $2 / 0084 / 16$ and $1 / 0136 / 18$ grants, the project $315 / 2019 / \mathrm{FaF}$ (IGA UVPS Brno) and also the following project implementations: TRANSMED, ITMS: 26240120008 and ITMS: 26240220071 supported by the Research \& Development Operational Programme funded by the ERDF.

\section{References}

1 Bianchini G, Balko JM, Mayer IA, Sanders ME and Gianni L: Triple-negative breast cancer: challenges and opportunities of a heterogeneous disease. Nat Rev Clin Oncol 13: 674-690, 2016. PMID: 27184417. DOI: 10.1038/nrclinonc.2016.66

2 Stovgaard ES, Nielsen D, Hogdall E and Balslev E: Triple negative breast cancer - prognostic role of immune-related factors: a systematic review. Acta Oncologica 57: 74-82, 2017. PMID: 29168430. DOI: 10.1080/0284186X.2017.1400180 
3 Barbieri F, Viale M, Sparatore F, Schettini G, Favre A, Bruzzo C, Novelli F and Alama A: Antitumor activity of a new orally active organotin compound: a preliminary study in murine tumor models. Anticancer Drugs 13: 599-604, 2002. PMID: 12172505.

4 Brtko J and Dvorak Z: Triorganotin compounds - ligands for "rexinoid" inducible transcription factors: biological effects. Toxicol Lett 234: 50-58, 2015. PMID: 25683035. DOI: $10.1016 /$ j.toxlet.2015.02.009

5 Hunakova L, Macejova D, Toporova L and Brtko J: Anticancer effects of tributyltin chloride and triphenyltin chloride in human breast cancer cell lines MCF 7 and MDA-MB-231. Tumor Biol 37: 6701-6708, 2016. PMID: 26662104. DOI: 10.1007/s13277$015-4524-6$

6 Tabassum S and Pettinary C: Chemical and biotechnological developments in organotin cancer chemotherapy. J Organomet Chem 691: 1761-1766, 2006. DOI: 10.1016/j.jorganchem. 2005. 12.033

7 Hunakova L and Brtko J: Sn- and Ge-triorganometallics exert different cytotoxicity and modulation of migration in triplenegative breast cancer cell line MDA-MB-231. Toxicol Lett 279: 16-21, 2017. PMID: 28709983. DOI: 10.1016/j.toxlet. 2017. 07.879

8 Brtko J and Dvorak Z: Nuclear retinoid/retinoid X receptors and their endogenous and xenobiotic ligands in metabolism, differentiation and cancer treatment. Toxicol Lett 229: S5-S6, 2014. DOI: $10.1016 /$ j.toxlet.2014.06.046

9 Macejova D, Toporova L and Brtko J: Effects of natural ligands and synthetic triorganotin compounds of nuclear retinoid $\mathrm{X}$ receptors in human MCF 7 breast cancer cell line. Gen Physiol Biophys 36: 481-484, 2017. PMID: 28836501. DOI: 10.4149/ gpb_2017038

10 Nakanishi T, Nishikawa J, Hiromori Y, Yokoyama H, Koyanagi M, Takasuga S, Ishizaki J, Watanabe M, Isa S, Utoguchi N, Itoh N, Kohno Y, Nishihara T and Tanaka K: Trialkyltin compounds bind retinoid $\mathrm{X}$ receptor to alter human placental endocrine functions. Mol Endocrinol 19: 2502-2516, 2005. PMID: 15941851. DOI: $10.1210 /$ me.2004-0397

11 leMaire A, Grimaldi M, Roecklin D, Dagnino S, Vivat-Hannah $\mathrm{V}$, Balaguer $\mathrm{P}$ and Bourguet $\mathrm{W}$ : Activation of RXR-PPAR heterodimers by organotin environmental endocrine disruptors. EMBO Rep 10: 367-373, 2009. PMID: 19270714. DOI: 10.1038/embor.2009.8

12 Toporova L, Macejova D and Brtko J: Radioligand binding assay for accurate determination of nuclear retinoid $\mathrm{X}$ receptors: a case of triorganotin endocrine disrupting ligands. Toxicol Lett 254: 32-36, 2016. PMID: 27153798. DOI: 10.1016/j.toxlet. 2016. 05.005

13 Hunakova L, Gronesova P, Horvathova E, Chalupa I, Cholujova $\mathrm{D}$, Duraj $\mathrm{J}$ and Sedlak J: Modulation of cisplatin sensitivity in human ovarian carcinoma A2780 and SKOV3 cell lines by sulforaphane. Toxicol Lett 230: 479-486, 2014. PMID: 25159039. DOI: 10.1016/j.toxlet.2014.08.018

14 Bodo J, Hunakova L, Kvasnicka P, Jakubikova J, Duraj J, Kasparkova J and Sedlak J: Sensitization for cisplatin-induced apoptosis by isothiocyanate E-4IB leads to signaling pathways alterations. Br J Cancer 95: 1348-1353, 2006. PMID: 17060935. DOI: $10.1038 /$ sj.bjc.6603434

15 Stehlik P, Paulikova H and Hunakova L: Synthetic isothiocyanate indole-3-ethyl isothiocyanate (homoITC) enhances sensitivity of human ovarian carcinoma cell lines A2780 and
A2780/CP to cisplatin. Neoplasma 57: 473-481, 2010. PMID: 20568902.

16 Hunakova L, Sedlakova O, Cholujova D, Gronesova P, Duraj J and Sedlak J: Modulation of markers associated with aggressive phenotype in MDA-MB-231 breast carcinoma cells by sulforaphane. Neoplasma 56: 548-556, 2009. PMID: 19728765.

17 Hunakova L, Horvathova E, Majerova K, Bobal P, Otevrel J and Brtko J: Genotoxic effects of tributyltin and triphenyltin isothiocyanates, cognate RXR ligands: comparison in human breast carcinoma MCF 7 and MDA-MB-231 cells. Int J Mol Sci 20: 1198, 2019. PMID: 30857277. DOI: 10.3390/ijms20051198

18 Seltzer R: Reactions of organotin chlorides with the cyanodithioimidocarbonate anion. J Org Chem 33: 3896-3900, 1968. DOI: $10.1021 /$ jo0 $1274 \mathrm{a} 044$

19 Wharf I: Studies in aryltin chemistry. Part 5. Tin-119 and carbon-13 NMR spectra of some tetra- and triaryltin compounds. Inorg Chim Acta 159: 41-48, 1989.

20 Mosmann T: Rapid colorimetric assay for cellular growth and survival: application to proliferation and cytotoxicity assays. J Immunol Methods 65: 55-63, 1983. PMID: 6606682. DOI: 10.1016/0022-1759(83)90303-4

21 Gabelova A, Slamenova D, Ruzekova L, Farkasova T and Horvathova E: Measurement of DNA strand breakage and DNA repair induced with hydrogen peroxide using single cell gel electrophoresis, alkaline DNA unwinding and alkaline elution of DNA. Neoplasma 44: 380-388, 1997. PMID: 9605012.

22 Krishnamachary B, Penet MF, Nimmagadda S, Mironchik Y, Raman V, Solaiyappan M, Semenza GL, Pomper MG and Bhujwalla ZM: Hypoxia regulates CD44 and its variant isoforms through HIF- $1 \alpha$ in triple negative breast cancer. PLoS One 7: e44078, 2012. PMID: 22937154. DOI: 10.1371/journal.pone. 0044078

23 Loh TJ, Moon H, Cho S, Jang H, Liu YC, Tai H, Jung DW, Williams DR, Kim HR, Shin MG, Liao DJ, Zhou J, Shi W, Zheng $\mathrm{X}$ and Shen H: CD44 alternative splicing and hnRNP A1 expression are associated with the metastasis of breast cancer. Oncol Rep 34: 1231-1238, 2015. PMID: 26151392. DOI: 10.3892/or.2015.4110

24 Li J, Zha XM, Wang R, Li XD, Xu B, Xu YJ and Yin YM: Regulation of CD44 expression by tumor necrosis factor- $\alpha$ and its potential role in breast cancer cell migration. Biomed Pharmacother 66: 144-150, 2012. PMID: 22386367. DOI: 10.1016/j.biopha.2011.11.021

25 Saito H, Kono Y, Murakami Y, Shishido Y, Kuroda H, Matsunaga T, Fukumoto Y, Osaki T, Ashida K and Fujiwara Y: Highly activated PD-1/PD-L1 pathway in gastric cancer with PD-L1 expression. Anticancer Res 38: 107-112, 2018. PMID: 29277762. DOI: 10.21873 /anticanres.12197

26 Francisco LM, Sage PT and Sharpe AH: The PD-1 pathway in tolerance and autoimmunity. Immunol Rev 236: 219-242, 2010. PMID: 20636820. DOI: 10.1111/j.1600-065X.2010.00923.x

27 Wang Z-Q, Milne K, Derocher H, Webb JR, Nelson BH and Watson PH: PD-L1 and intratumoral immune response in breast cancer. Oncotarget 8: 51641-51651, 2017. PMID: 28881675. DOI: $10.18632 /$ oncotarget.18305

28 Mittendorf EA, Philips AV, Meric-Bernstam F, Qiao N, Wu Y, Harrington S, Su X, Wang Y, Gonzalez-Angulo AM, Akcakanat A, Chawla A, Curran M, Hwu P, Sharma P, Litton JK, Molldrem $\mathrm{JJ}$ and Alatrash G: PD-L1 expression in triple-negative breast cancer. Cancer Immunol Res 2: 361-370, 2014. PMID: 24764 583. DOI: $10.1158 / 2326-6066 . C I R-13-0127$ 
29 Botti G, Collina F, Scognamiglio G, Rao F, Peluso V, De Cecio R, Piezzo M, Landi G, De Laurentiis M, Cantile M and Di Bonito M: Programmed death ligand 1 (PD-L1) tumor expression is associated with a better prognosis and diabetic disease in triple negative breast cancer patients. Int J Mol Sci 18: e459, 2017. PMID: 28230773. DOI: 10.3390/ijms18020459

30 Zhang M, Sun H, Zhao S, Wang Y, Pu H, Wang Y and Zhang Q: Expression of PD-L1 and prognosis in breast cancer: a metaanalysis. Oncotarget 8: 31347-31354, 2017. PMID: 28430626. DOI: $10.18632 /$ oncotarget.15532

31 Nanda R, Chow LQM, Dees EC, Berger R, Gupta S, Geva R, Pusztai L, Pathiraja K, Aktan G, Cheng JD, Karantza V and Buisseret L: Pembrolizumab in patients with advanced triple- negative breast cancer: phase Ib KEYNOTE-012 study. J Clin Oncol 34: 2460-2467, 2016. PMID: 27138582. DOI: 10.1200/ JCO.2015.64.8931

32 Gibson J: Anti-PD-L1 for metastatic triple-negative breast cancer. Lancet Oncol 16: e264, 2015. PMID: 25936988. DOI: $10.1016 /$ S1470-2045(15)70208-1
Received July 13, 2019

Revised July 26, 2019

Accepted August 1, 2019 